\title{
Distintos tipos de una pandemia
}

\author{
Valeria de los Ríos \\ Pontificia Universidad Católica de Chile
}

¿Cuánto tiempo ha pasado desde que todo esto empezó? Intento hacer la cuenta, pero a pesar de que las fechas son más o menos claras, la percepción del tiempo en mi memoria resulta borrosa e irreal. El estado de emergencia que se había impuesto ya externamente desde el 18 de octubre, ahora era un estado interno, que nos obligaba al aislamiento y a la modificación de nuestras prácticas, además de sumirnos en un estado de angustia por la incertidumbre y por el temor al contagio.

Nos encerramos para cuidarnos, porque lejos de ser humanos omnipotentes, ante el virus nos revelábamos como lo que éramos: seres vulnerables y frágiles. Pero una vez cerrada la puerta hacia el mundo, otra historia comenzaba a desplegarse: una historia hecha de múltiples historias, propias y ajenas; historias en las que se involucraban afectos y formas de vida, estructuras políticas y de organización doméstica; materialidades y medios de comunicación; historias de desigualdades, de formas de trabajo y de relaciones de poder. Curiosamente, al separarnos del mundo - eso que según Hannah Arendt nosotros mismos construimos - se volvía cada vez más imperiosa su transformación.

Durante el primer semestre enseñé cursos sobre medios y teoría del cine. A dos semanas del inicio del año lectivo, nos vimos de pronto mediados por pantallas, multiplicados los rostros en una grilla que podía convertirse en un gran agujero negro que consumía gestos, afectos y tiempo. Semana a semana nuestros cuerpos, sentados frente a la pantalla, esperaban encontrar la mirada del otro, recuperar el aura de la sala de clases, que es mucho más que la suma de unos cuantos individuos conectados al mismo tiempo. Aunque no lo logramos, aprendimos a usar las prótesis que el aparato nos proponía y nos apropiamos de lo que pudimos - micrófonos, teclados y cámaras - para comunicar lo que hacía falta. Mis estudiantes y yo nos supimos privilegiados por tener acceso a aquello de los que muchos carecen; y aprendimos, casi a la fuerza, que el conocimiento, más que un conjunto de certezas, es un modo de hacerse preguntas, porque siempre estamos rodeados de incertidumbre y, cada vez más, de información falsa. Tuvimos la experiencia práctica de que los medios — aquello que a veces pensamos que es transparente- tiene una materialidad insoslayable, como la de un vidrio sobre el que caen las gotas de lluvia en una película de Raúl Ruiz. 
El tiempo ya no se medía en días, semanas y meses, sino que en lo que demoro en ir de la cama al living, y de allí a la cocina para preparar el almuerzo; lo que dura el detergente o lo que demora en crecer mi pelo, tu barba o las canas que se empezaron a asomar. Pero así como había un tiempo que se medía en el cuerpo, también había otros tiempos: el tiempo de las noticias, el de los gatos que duermen la siesta sobre nuestras camas, el tiempo de conmemoraciones, unos dientes de leche que caen, el recuerdo de una infancia en dictadura, de mi abuela que ya no está, el paso de las estaciones, la caída y llegada de las hojas, el crecimiento de las plantas en jardín. Pienso y agradezco: cuánto me ha enseñado la literatura y el cine sobre el paso del tiempo. Cuánto me falta por aprender sobre el cultivo de la vida vegetal.

Este año termino un proyecto de investigación que duró tres años sobre nuevos materialismos y enseño un seminario de grado sobre el tema. Leemos sobre materialidades y sus agencias, pensamos sobre lo inanimado como una forma de vitalidad, nos informamos sobre la crítica al antropocentrismo y sobre el cambio climático. Pienso en el virus, que no está precisamente vivo sino hasta que encuentra un organismo en el que desarrollarse, pienso en su agencia que llega a tenernos encerrados por meses y nos fuerza a cambiar nuestras costumbres. También pienso en que una temporalidad exclusivamente humana es reductora, que la aceleración de nuestra época es la de un tiempo marcado por la economía y su substrato extractivo, que es la que hace posible el litio de las baterías de nuestros teléfonos y computadores, y al mismo tiempo es causante de múltiples formas de vida precaria alrededor del mundo. Como las plantas que están interconectadas y generan oxígeno sin el cual no podemos sobrevivir, el mundo está hecho de redes en las que convivimos con elementos materiales y afectivos. Pienso en la historia como relato e imagino cómo podemos cambiarla. Pienso en intercambiar semillas $\mathrm{y}$ transformar el pasto en bosque o en huerto. Esto se transforma en un proyecto en medio de la pandemia. Desde un punto de vista no antropocéntrico, pienso en cómo sería contar la historia de la catástrofe de la civilización humana y del ambiente. Pienso que otros ya lo han hecho — escritores, artistas, minorías étnicas-. Otros lo siguen haciendo. Pienso que llevamos demasiado tiempo en una pesadilla de la que es necesario despertar. En algunas semanas podremos votar si queremos cambiar una constitución fraguada en dictadura. Estar en el presente implica no tener todas las respuestas. Antonio Gramsci proponía: pesimismo de la inteligencia, optimismo de la voluntad. 